\title{
Gymnastics' centre of gravity: the Fédération Internationale de Gymnastique, its governance and the Cold War, 1956-1976
}

\author{
Georgia Cervin , Claire Nicolas, Sylvain Dufraisse, Anaïs Bohuon \& Grégory \\ Quin
}

To cite this article: Georgia Cervin , Claire Nicolas, Sylvain Dufraisse, Anaïs Bohuon \& Grégory Quin (2017): Gymnastics' centre of gravity: the Fédération Internationale de Gymnastique, its governance and the Cold War, 1956-1976, Sport in History

To link to this article: http://dx.doi.org/10.1080/17460263.2017.1363081

曲 Published online: 06 Sep 2017.

Submit your article to this journal ๘

Q View related articles ¿ᄌ

View Crossmark data $₫$ 


\title{
Gymnastics' centre of gravity: the Fédération Internationale de Gymnastique, its governance and the Cold War, 1956-1976
}

\author{
Georgia Cervin (D) ${ }^{a}$, Claire Nicolas ${ }^{b}$, Sylvain Dufraisse ${ }^{c}$, Anaïs Bohuon $^{d}$ and \\ Grégory Quin ${ }^{b}$
}

${ }^{a}$ School of Humanities, History Discipline, University of Western Australia, Crawley, Australia; b Institut des Sciences du Sport de I'Université de Lausanne, Lausanne, Switzerland; 'UFR STAPS,

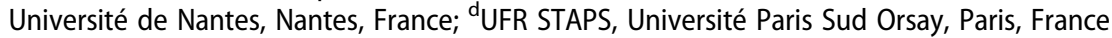

\begin{abstract}
Founded as the Bureau Des Fédérations Européennes De Gymnastique in 1881, the International Gymnastics Federation (FIG) was officially created in 1922. However, despite having over 100 national associations affiliated by the end of the twentieth century, it was dominated by Europeans until relatively recently. In particular, the former communist bloc of Eastern Europe had a particular hold on gymnastics from the 1950s onwards. This article uses the FIG as a case study to highlight the institutional, political and ideological rivalries within international sport. It reveals such influences on the sportification of gymnastics and, in doing so, offers new insights into the history of the Cold War, including the USSR's ascension to the international sporting scene, and its power surrounding the 'South Africa ban' due to its Apartheid policy. Thus, this work allows us to understand how the FIG's policies were, from an early stage, embedded in a twofold dynamic of EastWest and North-South. Our study is based on official and administrative documents from national associations and the FIG, and on press review from several European countries.
\end{abstract}

KEYWORDS Gymnastics; Cold War; international institution; Olympic Games; Europe

\section{Introduction}

Between 1956 and 1976, the Fédération Internationale de Gymnastique (FIG) saw two Swiss officials successively ascend to its presidency, Charles Thoeni and Arthur Gander. This signified the central role of Swiss gymnastics officials ${ }^{1}$ both technically and politically ${ }^{2}$ within the international federation, before influence shifted East with the arrival of Russian Yuri Titov as head of the international institution, in the context of the Soviet Union's overwhelming success in the sport. Meanwhile, it was also during this period

CONTACT Grégory Quin $\otimes$ gregory.quin@unil.ch 을 Institut des Sciences du Sport de l'Université de Lausanne, Switzerland

(c) 2017 The British Society of Sports History 
that the FIG transformed its governance, both to ensure the proper management of the different gymnastic disciplines under its responsibility, and to confront the geopolitical issues affecting competitive gymnastics in the context of the Cold War. ${ }^{3}$

Founded in 1881, the FIG (European Gymnastics Federation between 1881 and 1921) is one of the oldest international sports institutions, whose influence initially extended beyond the competition - particularly in the early days, to encourage the institutionalisation of gymnastics in schools across Europe - and whose jurisdiction assumed various disciplines (artistic gymnastics, rhythmic gymnastics, trampoline, tumbling) over the twentieth century. Conclusions on sports' international relations in the interwar period by such scholars as James Riordan and Pierre Arnaud has stressed that 'Europeanisation and universalisation of sport are the remarkable traits of the post-1918 world'. ${ }^{4}$ Similarly, Barbara Keys emphasises the influence of authoritarian regimes on the development of sport in the 1930s. ${ }^{5}$ However, the time of the Cold War must be considered a second moment of the internationalisation of sport. ${ }^{6}$ Various historians have established that, on the pitch and in the arena, the two blocks competed against each other using athletes to prove their nation's ascendancy. ${ }^{7}$ But few have examined how such conflict was also present within the administrative and governing functions of the international federations. Using the FIG as a case study, in this article we argue that much like the playing fields, sports institutions are also places of both conflict and collaboration between officials from the two blocs, revealing deep complexities in Cold War international relations, beyond simple ideological opposition.

Like many other international federations, the FIG would experience strong growth in the aftermath of the Second World War, with the integration of the Soviet Union and some of its satellites into the international sports movement and, according to Thoeni, the FIG pursuing its mission for the good of physical education and the youth all over the world'. ${ }^{8}$ Despite such lofty goals, and the educational ambitions of its leaders - including Thoeni himself, who had occupied the General Secretary position at the FIG since $1938^{9}$ - from the beginning of the 1950s the core of FIG's aims were reoriented around high performance gymnastics.

This article has a double ambition, both to understand the structuration of international gymnastics in the context of the Cold War, including its singular position throughout the decolonisation processes and, more broadly, to expand our knowledge of international sports geopolitics in the second half of the twentieth century. In doing so, we aim to demonstrate the manifestation of ideological balance within a sport that remains under-researched. Indeed, one of the founding elements of our approach is the almost total absence of historiography devoted to gymnastics as a sport and its international governance. ${ }^{10}$ This paucity is a major paradox if we consider the 
number of works that seek to analyse the 'educational' dimensions of gymnastics since the late nineteenth century, both at school and in a wider context in the different currents of modern pedagogy. ${ }^{11}$

Indeed, the first step in building our argument was to contextualise the governance of international gymnastics within the wider international sports federation movement. Thus, we identified key moments and issues in the governance of other sports, to use as a comparison with gymnastics. We have done so by using archives and printed sources from gymnastics' institutions, mainly the complete collection of official quarterly FIG Bulletins, from 1956 to 1976, ${ }^{12}$ supplemented by documents from the Swiss Gymnastics Federation (Société Fédérale de Gymnastique - SFG) and the International Olympic Committee (IOC).

In the following, we begin with an analysis of the globalisation of the FIG, as it transitioned from a European organisation to one with global aims and reach, even it did remain euro-centric. From there, we examine the structures within the FIG that emerged to govern its growing repertoire of disciplines, focusing on what happened in those committees that were held within the FIG committees responsible for each discipline (the Executive Committee (EC), the Women's Technical Committee (WTC), the Men's Technical Committee (MTC) and the Modern Gymnastics Committee (MGC)). So there is a sort of double-process affecting FIG's governance, one external based on the globalisation of sport after the Second World War and one internal based on the sportification of several gymnastics' disciplines. Finally, on this foundation we discuss the geopolitical conflict and collaboration that occurred within the FIG, first through the example of the South Africa question, before exploring the domination of the East - both Asiatic and European - on the medal tallies, demonstrating both how the governance of international gymnastics was affected by wider issues affecting international relations during this period and how gymnastics could contribute to rethinking our understanding of the ideological opposition of the Cold War. Throughout this article we refer to governance, and in this context, it should be understood as the systems and structures that have contributed to how the sport is practised and restricted, and by whom these policies have been created and to whom they apply.

\section{Making the Fédération Internationale de Gymnastique more global}

Within the FIG, as elsewhere in sports, geopolitical upheavals following both decolonisation and the Cold War tested internal political balances. Moreover, the special place given to women's sport in the Federation (unlike other sports federations) would make the FIG unique within the international sports system. 
In its early years, the Federation was dominated by Europe, especially northern Europe. At its foundation, the FIG consisted of the member nations of Belgium, France, Italy and the Netherlands, and between the late nineteenth and the interwar period it would integrate several Eastern European federations: Hungary, Romania, Bulgaria, Poland, Czechoslovakia and Yugoslavia. There were a few exceptions to this early Euro-centrism, with Canada joining in 1899, the USA in 1921 and Egypt (under the name 'Unified Arabic Republic') in 1910. So it is fair to claim that the organisation was a predominantly European body until the Second World War, like many other 'international' sports organisations. ${ }^{13}$

Between 1945 and 1950, the new countries seeking membership were mainly non-European: Mexico, South Africa, Austria, Iran, Argentina, Colombia, Cuba, the Soviet Union and Portugal, in the context of a greater opening towards Asia (Iran in 1947 and Japan in 1951) and South America. In the meantime, the formal affiliation of the Soviet Union, at the Stockholm Congress in 1949, was similar in its 'conditions', to what has already been described for other sports just after the Second World War, ${ }^{14}$ particularly regarding claims towards a Vice-presidency and to have Russian recognised as an official language.

Thus, until 1950, the heart of international gymnastics remained very European and the main bodies of the institution tended to reflect this. For instance, the Swiss FIG General Secretary, Thoeni, complained in his 1953 address to the FIG's Congress that '[in his] view, the Olympic Games of 1956 were awarded to a country [Australia] which was too far from the core of the international sports movement and that it was a mistake' ${ }^{15}$ Theoni's assertion reflects the very Euro-centric view of one of the most influential leaders in international gymnastics - a perspective that was also demonstrated when several newcomers joined the FIG after the Second World War.

The gradual affiliation of countries from Eastern Europe and from outside Europe after 1956 imposed new debates within the FIG, and questions of international relations, particularly with the USSR. For instance, even though the Soviet Gymnastics Federation was part of the FIG, Swiss gymnastics officials forbade their country to have contact with the Soviet Union in a gymnastics context, and severely controlled engagements with all socialist satellite states from 1957 onwards. ${ }^{16}$ They did so in support of their country's boycott of the 1956 Games, protesting the Soviet invasion of Hungary. ${ }^{17}$ Pointed correspondence between the IOC and SFG highlights the incompatibility of national interests and international sports participation. When the SFG invited IOC Chancellor Otto Mayer to its fundraising ball in November 1956, the latter declined as follows.

Independent of the regrettable attitude taken by the directors of the SFG with regards to the Olympic movement and who change nothing of the sympathies 
with your organization's motives, I fear that I won't be able to attend your festivities while the Hungarian people are oppressed, suffering, and enduring under a foreign yoke. ${ }^{18}$

A second example of these geopolitical conflicts is revealed when, in 1957, Syria, the People's Republic of China and the German Democratic Republic applied to join the FIG. While the former two were accepted, the East German Federation was refused for the sixth time in a row. Although the delegates from Luxembourg, Pierre Hentges, and the Soviet Union, Nicolas Mironov - who were also Chairman and Vice-Chairman of the Men's Technical Committee (MTC) respectively - spoke in favour of the East German Federation, the intervention of the Belgian representative at the FIG congress was decisive. Echoing the mantra of IOC President Avery Brundage, he maintained that a country could be only be represented by one federation. Despite the forced political separation of Germany following the Second World War, the sports world would only acknowledge it as a single nation, and attempted to use sport to foster cooperation between East and West Germany. 'The FIG has admitted only Belgian federation,' the Belgian official argued, 'while there are four different in the country including three which are pursuing political aims ${ }^{19}{ }^{19}$ However, this position prompted the indignation of the Czechoslovak Klinger, whose views, when juxtaposed with those of the MTC members above, reflect the idiosyncrasies of early twentieth century international sporting institutions' commitment to remaining apolitical, yet concurrently promoting sport a tool for cooperation:

[My] country has been an FIG member since the beginning of its history. It is also the first time that we speak about politics within the institution. We are gymnasts and our goal is not to make politics but to collaborate around gymnastics. $^{20}$

Indeed, in terms of expanding membership, we see a third unique scenario in the FIG. While many international federations saw the number of their members grow quickly in the mid- $1950 \mathrm{~s}^{21}$ following decolonisation on the African continent, this was not the case with FIG. Although Middle Eastern, South American and Asian federations (see Table 1) swelled the FIG ranks as non-Western members, the absence of African states would have important consequences around the South African question that would erupt a few decades later.

If it is difficult to clearly explain the absence of African federations within the FIG, it is probably a consequence of the small development of sportive gymnastics on the continent, outside of some specific countries such as South Africa or Egypt. Gymnastics was introduced in African colonies through the military and educational systems, via Swedish and German gymnastics. The practice was mainly directed towards drill and gymnastic displays by military men and schoolchildren (including after independence). It was therefore set aside 
Table 1. Affiliation date from FIG members (1881-1971). ${ }^{a}$

\begin{tabular}{|c|c|c|c|}
\hline 1881 & $\begin{array}{l}\text { Belgium } \\
\text { France } \\
\text { Italy } \\
\text { Netherland }\end{array}$ & 1950 & Portugal \\
\hline 1897 & Czechoslovakia & 1951 & $\begin{array}{l}\text { West Germany } \\
\text { Brazil } \\
\text { Japan }\end{array}$ \\
\hline 1898 & Hungary & 1952 & $\begin{array}{l}\text { India } \\
\text { Israel }\end{array}$ \\
\hline 1899 & Canada & 1954 & Australia \\
\hline 1900 & Luxembourg & 1956 & Syria \\
\hline 1907 & $\begin{array}{l}\text { Romania } \\
\text { Yugoslavia }\end{array}$ & 1957 & East Germany \\
\hline 1910 & Egypt under the name of "Unified Arabic Republic" & 1958 & $\begin{array}{l}\text { North Korea } \\
\text { Pakistan } \\
\text { Venezuela }\end{array}$ \\
\hline 1921 & United States of America & 1959 & $\begin{array}{l}\text { South Korea } \\
\text { Peru } \\
\text { Tunisia }\end{array}$ \\
\hline 1922 & Poland & 1960 & Morocco \\
\hline 1923 & Switzerland & 1961 & $\begin{array}{l}\text { Chile } \\
\text { Turkey }\end{array}$ \\
\hline 1924 & Finland & 1962 & $\begin{array}{l}\text { Lebanon } \\
\text { Mongolia } \\
\text { New Zealand }\end{array}$ \\
\hline 1926 & Denmark & 1964 & $\begin{array}{l}\text { Algeria } \\
\text { China } \\
\text { Kuwait } \\
\text { Malaysia } \\
\text { Philippines }\end{array}$ \\
\hline 1931 & Bulgaria & 1965 & Greece \\
\hline 1933 & Spain & 1966 & $\begin{array}{l}\text { Cambodia } \\
\text { Hong Kong } \\
\text { Ecuador }\end{array}$ \\
\hline 1935 & $\begin{array}{l}\text { Norway } \\
\text { Sweden }\end{array}$ & 1967 & Indonesia \\
\hline 1936 & Great-Britain & 1968 & Libya \\
\hline 1945 & Mexico & 1969 & Myanmar \\
\hline 1947 & $\begin{array}{l}\text { South Africa } \\
\text { Austria } \\
\text { Iran }\end{array}$ & 1970 & $\begin{array}{l}\text { Guatemala } \\
\text { Panama } \\
\text { San Marino }\end{array}$ \\
\hline 1948 & $\begin{array}{l}\text { Argentina } \\
\text { Colombia } \\
\text { Cuba }\end{array}$ & 1971 & $\begin{array}{l}\text { Lesotho } \\
\text { Liechtenstein }\end{array}$ \\
\hline 1949 & Soviet Union & & \\
\hline
\end{tabular}

${ }^{\mathrm{a}}$ FIG Official Bulletin, no. 4 (1971): 18-19, FIG Archives.

from the rise of sporting associations orchestrated by the 'Educated African Elite' from the end of the colonial era and onwards (Table 2). ${ }^{22}$

More generally, we can see from the maps in (Figure 1, 1957, 1967 and 1977) that the governing bodies of the FIG remained strongly European-oriented. The only non-Occidental country that was part of the governing bodies was Japan, with representation on the MTC and WTC and as Vice President of the EC. The USSR remained the only Eastern member of the EC until the 1970s, backed up by Western countries within the MTC and WTC (Figure 1(a)-(c)). 
Table 2. Total Number of FIG affiliated nations. ${ }^{a}$

\begin{tabular}{lc}
\hline Date & Affiliated countries \\
\hline 1881 & 4 \\
1903 & 8 \\
1921 & 12 \\
1938 & 20 \\
1950 & 28 \\
1954 & 37 \\
1978 & 69 \\
2013 & 127 \\
\hline
\end{tabular}

abie Grossfeld, 'Changes during the 110 Years of the World Artistic Gymnastics Championships', Science of Gymnastics Journal 6, no. 2 (2014): 5-27.

At the upper level of the FIG governing bodies, the Presidency and VicePresidency of the EC were among the historical builders of the federation, and these positions were held by Sweden, Switzerland and Denmark, along with the USA. But, from the 1970s, the aforementioned rise of Yuri Titov to the Vice-Presidency and then the Presidency of the Committee changed the game. Even though Switzerland remained powerful, Sweden and Denmark 'disappeared' from the Executive Committee. To conclude on this mapping of the governing bodies of the FIG, beyond the changes among (Vice)-Presidency, we clearly see a mingling between East and West, especially around technical decisions (MTC and WTC).

On one hand, the federation was one of the few to feature such a large number of women athletes. On the other, gymnastics would indeed play an essential role in the sportification of women's sports after $1945 .^{23}$ Thus, the gymnastics of the twentieth century, 'as an institution, gradually opened to women, including the creation of consistent practices for "canons" of femininity, inspired by aesthetic and artistic codes of dance'. ${ }^{24}$ In addition, women's participation took on new meaning with the inclusion of gymnasts from the Communist sphere. In the 1950s, the emblematic figures of Women's Artistic Gymnastics (WAG) were women of the Eastern bloc. Soviet gymnasts combined supremacy and incredible performances and embodied values of socialist youth, in the USSR and abroad. Nine-time Olympic gold medallist, Russian Larissa Latynina was a role model for Soviet youth, presented as a young woman full of self-denial with an impressive work ethic, reconciling academic success with a taste for culture and highlevel sport, while highlighting the Soviet feminine appearance. ${ }^{25}$ Two decades later, the young Romanian Nadia Comăneci was credited with the first perfect score of '10' in Olympic history, at the 1976 Montreal Games, becoming a new emblem of female perfection. Thus, as Sylvain Dufraisse noted, in the Soviet Union 'the promotion of champions could create role models for young Soviet girls as the embodiment of a new form of feminine ideal'. ${ }^{26}$ Graceful gymnasts such as Latynina and Comăneci in particular corresponded to this ideal, 
(a)

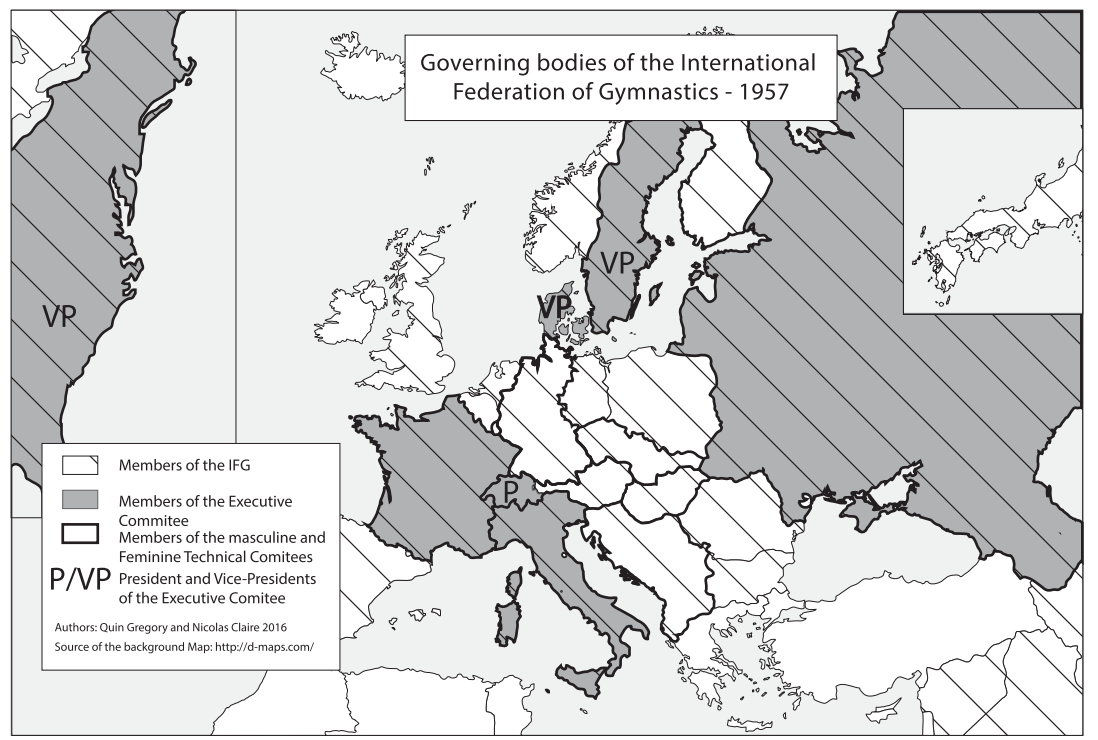

(b)

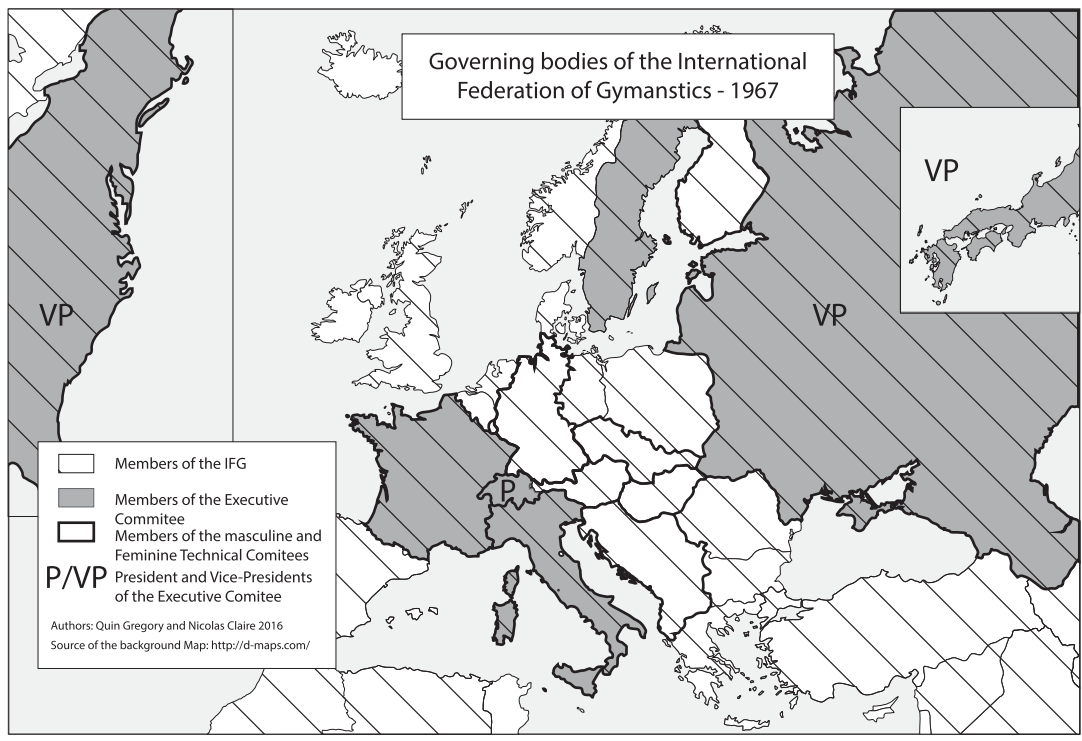

Figure 1. Successive maps showing the geographical repartition of the members of the Governing Bodies within the FIG. (a) 1957, (b) 1967 and (c) 1977.

representing 'perfect' European standards of femininity. ${ }^{27}$ As femininity became an issue within the Cold War, in Eastern countries and especially in Soviet Union, the promotion of women's gymnastics became important to counteract stereotypes about women athletes being too masculine. ${ }^{28}$ 
(c)

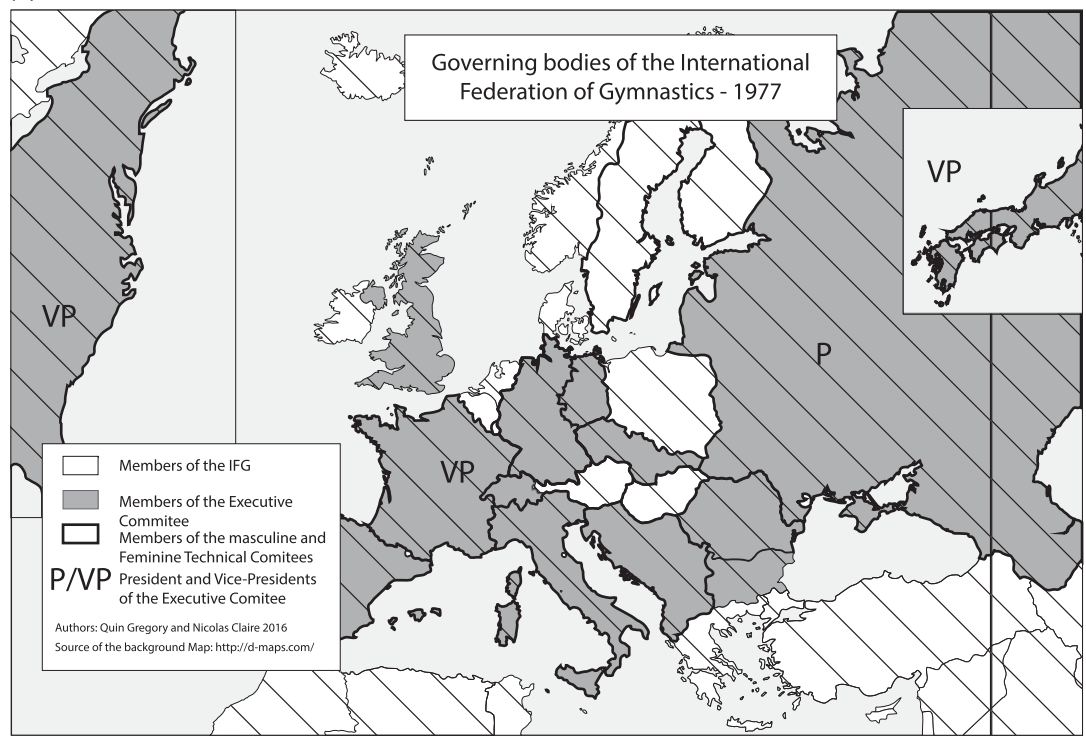

Figure 1. Continued.

\section{Developing governing bodies for international gymnastics}

Four different committees ruled the FIG in the 1970s: the EC, the WTC and the MTC, joined by the MGC in 1973 (which became the Rhythmic Gymnastics Technical Committee from 1975 onwards). ${ }^{29}$ Members of the various committees, elected by the delegates at the Congress, led the core of the Federation. In order to serve on a technical committee one had to hold a 'brevet', an international judging qualification (awarded by the FIG), because these committees were responsible 'for the creation of specific rules, for the codification of bodily elements, for the definition of the competitions, the certification of equipment or the organisation of the training for coaches and judges' ${ }^{30}$ They define sportive gymnastics. Despite detailed control of the disciplines being in the hands of the technical committees however, the EC is the main governing body of the FIG. It makes decisions regarding the admission of new members, the organisation of the major gymnastics events (Olympic Games, Gymnaestrada, World Championships, European Championships, etc.), as well as relations with the IOC, or regarding the judging difficulties that plagued the FIG's relationship with the Olympic movement. Oral histories, from Cervin's research, point to organised score-fixing throughout much of this period, ${ }^{31}$ a situation that the FIG noted ' ... can be in favour of a persistence of a certain corruption which would be very dangerous for our sport, even a vital danger,' referring to its detrimental effect on the FIG's position in the Olympic movement. ${ }^{32}$ In fact, one gymnast's account 
of biased judging from as early as 1948 specifically mentions Swiss Arthur Gander essentially admitting to conscious subjectivity, which continued long after Gander rose to the FIG Presidency in $1966 .{ }^{33}$

Although non-Western European federations have long been present in the FIG, as Klinger noted in 1953, the proportion of those nations within the governing committees would evolve after the 1970s. From 1946 to 1956, the Presidency was held by the Belgian Count Goblet d'Alviella (i.e. since the resumption of the FIG activity after the World War), before the election of Thoeni in 1956. At this point, only one Eastern bloc representative (from the Soviet Union) served on the eight-member EC. It would be another ten years, upon the election of Thoeni's successor and compatriot, Arthur Gander, that the Soviet Union was joined by Yugoslavia in the EC, even if Yugoslavians endeavoured to maintain an independent position. However, the Eastern bloc's influence was reinforced more concretely in 1973, first with the arrival of the Russian Yuri Titov - already influential on the international scene as a gymnast and official - and second with the entry of Hungarian Valerie Nagy-Herpich and a second Yugoslavian in the EC. This resulted in near parity in the FIG's main governing body, which was solidified several years later when Yuri Titov was elected to the presidency in 1977. However, this East-West representation remained firmly European. In fact, when Jim Barry became the first Australian elected to the EC in 1984, joined by members from China and the USA (although the latter had served on the EC before), Barry celebrated in a letter to the Australian gymnastics community that this finally 'removed the domination of Europe' within the FIG. ${ }^{34}$

Although the FIG developed in terms of geopolitical representation in the 1960s and 1970s, the gender balance did not. The proportion of women gymnasts did not correspond with their representation in the FIG's governance/ governing bodies. Despite having an all-female committee in charge of WAG (in parallel to the MTC), the EC, which oversaw the work of both groups, remained male-dominated until the end of the twentieth century. Indeed, the first woman to enter the EC was Berthe Villancher in 1969, followed by Valerie Nagy-Herpich in 1973, who replaced the latter. As both were successive Chairwomen of the WTC, it appears that their invitation to the EC was a result of holding this position, rather than reflecting a particularly gender inclusive governing structure. By 1976, they were still only two female members to 14 male members: the Italian Andreina Gotta and the East German Ellen Berger - again both leaders of their respective technical committees (MGC and WTC). However, based on the separation of the different gymnastics disciplines, the technical committees for women's artistic and rhythmic gymnastics afforded women real autonomy regarding FIG governance and the way it ruled its disciplines. It was only in 1977 that these two women served on the EC together, following the development of Rhythmic Gymnastics - a second women-only discipline arising from an increasingly 'masculine' WAG, ${ }^{35}$ 
which will be discussed shortly. Meanwhile, if the technical committees were composed of female officials for the WTC and male officials for the MTC, it demonstrates the FIG's preservation of the idea that sport can be both masculine and feminine, but always in separate categories and never mixed.

The EC echoed the affiliation dynamic in many other international federations, where senior officials were 'white men with European origins'. ${ }^{36}$ This pattern was not without consequence, as we will see later within the debate about the possible exclusion of the South African federation.

Nonetheless, it should not be inferred from the slow evolution of the composition of the EC that the FIG was monopolised by Western Europeans. The MTC and WTC saw their composition tilt to the east much faster than the EC. Since the early 1950s, the technical committees had been almost at parity between representatives of Western and Eastern Europe. Again, Hungary, Yugoslavia and the USSR were present, along with Czechoslovakia. Thus, representatives from the broader Europe provided the technical guidance of the Federation for men and women. During the 1969 election, the Eastern bloc even became a majority in the WTC (four members out of seven), yet remained under the chairmanship of the French Berthe Villancher. And the MTC, chaired by Arthur Gander since 1965, ${ }^{37}$ was half composed of representatives from Eastern Europe that same year. Notwithstanding the East-West representation demonstrated at the technical committee level, analysis of this membership reconfirms the Euro-centrism that dominated the organisation at all levels.

Finally, the creation of a Modern (later Rhythmic) Gymnastics Technical Committee (MGC) in 1973, chaired by the Italian Andreina Gotta, marked a turning point in the women's technical expertise and its international recognition. It also opened a new space of rivalry between the two blocs, even if the Eastern one had already proven its dominance since the first World Championship, organised in $1963 .{ }^{38}$ Becoming an Olympic sport at the 1984 Olympic Games, Rhythmic Gymnastics has since been dominated on the competition floor and in the governing committee by the Soviet bloc. Indeed, between 1973 and 1976, Hungary, the USSR, Czechoslovakia, Bulgaria and East Germany worked with Italy and West Germany in the MGC to govern the new discipline.

In fact, although the FIG offers a singular organisational profile in the landscape of international sport in the post-1945 world, it is a particularly remarkable case. Unlike most international sporting institutions, the FIG displayed notable diversity, with committees consisting of both Eastern bloc and Western countries, served by both men and women. Despite this relatively progressive position, the institution nonetheless reflected wider geopolitical turpitudes, which sometimes led to slower collaborations, and at other times to resistances in certain situations, under a growing technical domination of the 'East'. 


\section{Facing geopolitical turpitudes}

Like many other international sports institutions, ${ }^{39}$ the FIG had to face the transformations of geopolitical balances after the Second World War, with the emergence of a bipolar world where sports affiliation was often the first concern for 'new' independent governments.

In fact, after some first emblematic cases during the interwar period, such as around the Olympic Games in Berlin, political and sporting matters began to entwine and multiply in the 1950s. For instance, discussions around the allocation of visas for competitions organised beyond the Iron Curtain were a conflation of sport and politics, and such issues extended beyond logistics. Within gymnastics, tensions between judges were raised in the high stakes of Cold War sport, highlighting some corruption threats, ${ }^{40}$ while singular political events rippled throughout the sport, as in the case of the death of General Francisco Franco in November 1975, which resulted in an Eastern bloc boycott of the modern gymnastics world championships held in Madrid a few days later. ${ }^{41}$ In this section, our ambition is to focus on the transformation of the new East-West balance within the FIG and on positions taken by leaders facing debates around the exclusion of South Africa. But, more specifically, we will see how the East-West oppositions allowed the creation of new balances around the technical direction of all the disciplines included in the FIG, and the advent of gymnastics as a 'real' sport, distinct from its 'educational roots' in the nineteenth century.

\section{South Africa, between boycott and exclusion}

The iconic exclusion of South Africa from international sports institutions could be interpreted as the result of the commitment of 'transnational activist networks $^{42}$ from civil society, initially South African and African, before extending transnationally. When South Africa refused to let its non-White citizens represent it in sports - a symptom of the larger problem of apartheid - many nations and sporting institutions began to boycott relations with that nation, as sport was a highly visible platform for protest.

Let us highlight first the South African question within major international sports institutions, before taking a closer look at the FIG. Most prominent here was the IOC's action toward the state, which excluded South Africa from the Olympic Games - an unprecedented move for an 'apolitical' organisation that aimed for universal sports participation. First, in 1963, South Africa was not invited to participate in the Tokyo Games the following year, nor the following Games in Mexico 1968, due to its policy of apartheid. Then, South Africa would be permanently excluded from the Olympic movement from 1972 to 1992 . This exclusion was part of a long-term movement of concerns and sanctions from various federations, as Marc Keech has shown. ${ }^{43}$ For instance, in 1947, the International Table Tennis Federation had already 
issued sanctions against the South-African federation. Within the various international sports institutions issuing sanctions and exclusion against South Africa, such a policy was driven by the 'loose network' of 'Third World' African states (including the Middle East in particular), and Soviet states (led by the USSR). Considering that African sports leaders have been influential artisans of boycott strategies and exclusion ${ }^{44}$ is crucial for understanding the FIG's reaction within this framework.

Indeed, despite the absence of African representatives in the FIG, the South African 'case' became an issue from September $1966^{45}$ after Soviet Nikolaj Popov's proposal to disqualify South Africa. This rejected proposal would be repeated in subsequent years by members from the Soviet bloc, whose efforts supported their country's attempts to align with the 'Third World' (Table 3).

At each proposal, South Africa's defenders persistently highlighted its seniority within the FIG, as a member since 1947. Moreover, FIG leaders were decisively idealistic about the separation of sport and politics. For example, when the president of the South African Federation assured Thoeni that there was no racial discrimination in his country in 1966, Thoeni announced:

This is a purely political question which we do not have to deal with. For many years, the Federation of South Africa has been a member of the FIG and has always fulfilled its duties. I fully trust the honesty of its President. ${ }^{46}$

In his work on the South Africa question, Keech found that international sports institution leaders were mostly from the Western world and keen to circumvent any ban. ${ }^{47}$ In this context, EC members' reluctance to vote for the exclusion of their colleagues is unsurprising.

Moreover, the question of the supposed apolitical dimension of sport, defended as a major structure of the ideology of many federations - including the FIG - is omnipresent in the discussions on South Africa, as shown in Gander's statement in 1976. During the FIG Congress held at the Montreal Olympic Games in 1976 he deplored, 'the situation to which the IOC has to face up as a result of the political hold on sports', ${ }^{48}$ in reference to the boycott organised by African nations. Facing such difficulties, some pro-exclusion states tried to take short cuts. Thus, Romania proposed in June 1976 to replace the term 'neutrality' with 'non-discrimination' in the FIG Statutes, a

Table 3. South Africa exclusion proposal. ${ }^{a}$

\begin{tabular}{lll}
\hline Exclusion proposal & \multicolumn{1}{c}{ Date } & Results \\
\hline USSR & September 1966 & Refused \\
USSR & May 1969 & Refused \\
Poland, DDR, Romania, Czechoslovakia et USSR & September 1970 & Delayed \\
DDR, Czechoslovakia et USSR & August 1971 & Refused \\
DDR, Czechoslovakia et USSR & September 1973 & Refused \\
Bulgaria, DDR, Romania, USSR & September 1977 & Refused \\
\hline
\end{tabular}

${ }^{\mathrm{a}}$ FIG Official Bulletin, collection 1966-1977, FIG Archives. 
change that was accepted at the 1976 Congress, although without the desired impact on the South African question. Indeed, it proved the difficulty in distinguishing non-discrimination towards several federations or within one, as sporting bodies are 'not responsible for [their country's] political situation. ${ }^{, 49}$

The discussions in the FIG remained very similar to those in other sports institutions. Supporters of exclusion widely mobilised the Olympic values, including non-discrimination, as what Scarlett Cornelissen calls a 'rhetorical surrogate'..$^{50}$ They also relied on the widespread condemnation of apartheid in the international sports movement (IOC, International Federations) and elsewhere (United Nations). But, in reality, the struggle for the exclusion was based on broader political values such as 'race, anti-imperialism and self-determination. ${ }^{51}$ These values were common amongst communist and post-colonial states, and thus in the absence of post-colonial states within the FIG, promoted by the USSR, Romania, East Germany, Czechoslovakia and Bulgaria.

Despite recurrent efforts, the South African federation would never be banished from the FIG, although it was formally banned from several international competitions. However, even these bans did not originate within the FIG, instead coming at the request of the organising country or the IOC. We argue that the FIG's failure to acquiesce to the pro-exclusion group was rooted in the low representation of African federations in the organisation between 1950 and 1970. The member countries that drove the anti-apartheid struggle within the pioneering Table Tennis International Federation, and later the Fédération Internationale de Football Association were not represented in the FIG. Therefore, their absence limited the opportunity to put in place an effective lobbying for the exclusion. For comparison, we point to the intense lobbying done by Reginald S. Alexander within the IOC and by many representatives of postcolonial African states within FIFA, which ultimately led to complete or partial exclusion. ${ }^{52}$ Conversely, although members from the communist sphere worked to get the exclusion, they would never be numerous enough to tip the balance. Moreover, unlike the representatives of the African federations, the question of apartheid was not as ubiquitous as an issue of national and regional politics for East-European federations. ${ }^{53}$

\section{The sun rises in the east ... gymnastics between Sovietisation and sportivisation}

As governance and geopolitical representations within the FIG shifted between 1950 and 1975, so too did issues in the rankings at world-level competitions. The 'technical' and 'competitive' balance of artistic gymnastics was deeply upset during the first three decades of the Cold War, with the new success of the gymnasts from the Soviet Union and the almost complete disappearance of the Western European gymnasts from international podiums in the mid-1950s, as shown by Tables 4 and 5 . 
Table 4. Medals at the Olympic Games, by countries (1948-1980). ${ }^{a}$

\begin{tabular}{|c|c|c|c|c|}
\hline Country & 1948-1952-1956 & 1960-1964-1968 & 1972-1976-1980 & Total medals \\
\hline Finland & 5 & - & - & 5 \\
\hline Switzerland & 4 & - & - & 4 \\
\hline Italy & - & 1 & - & 1 \\
\hline United States & 1 & - & - & 1 \\
\hline USSR & 12 & 18 & 14 & 44 \\
\hline Unified Teamb & - & 1 & - & 1 \\
\hline GDR & - & 2 & 8 & 10 \\
\hline Bulgaria & - & - & 1 & 1 \\
\hline Romania & 2 & 1 & 4 & 7 \\
\hline Czechoslovakia & 2 & 5 & - & 7 \\
\hline Hungary & 5 & - & 2 & 7 \\
\hline Japan & 2 & 8 & 7 & 17 \\
\hline
\end{tabular}

${ }^{a}$ During the 1964 Olympic Games, the gymnasts from the United Team of Germany gained a bronze medal at the team competition, behind Japan and USSR.

${ }^{\mathrm{b}}$ For each Olympic Games, we do gather results from the team competitions and from the individual allaround competitions (feminine and masculine). In 1948, there was no individual all-around competition organised for women.

Table 5. Medals at the World Championships, by country (1950-1979). ${ }^{\text {a }}$

\begin{tabular}{lcccc}
\hline Country & $1950-1954-1958$ & $1962-1966-1970$ & $1974-1978-1979$ & Total medals \\
\hline Sweden & 2 & - & - & 2 \\
Austria & 1 & - & - & 1 \\
Finland & 2 & - & - & 2 \\
Switzerland & 4 & - & - & 4 \\
Italy & 1 & - & - & 1 \\
France & 2 & - & - & 2 \\
United States & - & - & - & 2 \\
Poland & 2 & - & 1 & 2 \\
Hungary & 1 & 2 & 17 & 2 \\
USSR & 12 & 8 & 7 & 43 \\
GDR & - & & - & 13 \\
Czechoslovakia & 5 & 12 & 3 & 4 \\
Romania & 1 & & 6 & 21 \\
Japan & 3 & & - & -
\end{tabular}

${ }^{\mathrm{a}}$ As for the Olympic Games, we do gather medals from both team competitions and the individual allaround competitions (masculine and feminine).

Observing the medals won during the Olympic Games, we could also argue that the sun rises 'twice' in the East, since, beyond the Soviet performance - or more broadly by gymnasts from the Eastern bloc - the other great nation of artistic gymnastics during the cold War was Japan. The Soviet Union dominated WAG, winning the team medal at every Olympic Games it entered over its 40 years, and most of the All-Around events ${ }^{54}$ and apparatus medals too. Moreover, when these Soviet champions were challenged, usurpers remained from the Eastern bloc, with gymnasts such as Věra Č́slavská, from Czechoslovakia, Nadia Comăneci from Romania, or the East German team. However, while these nations excelled in MAG too, success extended even further East to Japan. The extent of Japan's excellence is not visible in Tables 4 and 5, as it was only really influential in MAG, while the Soviet 
Union gained medals from both the men's and women's disciplines. Nonetheless, it was such a threat to the Soviet Union that action was taken. In 1973, the Soviet Union succeeded with a proposal to limit the number of finalists to two per country for apparatus finals and three per country for the All-Around, which according to a former EC member, was designed to limit Japan's medal haul in MAG. ${ }^{55}$

In addition to our analysis of influence on gymnastics through the FIG governing committee, broader hypotheses about gymnastics and local cultures might explain the transformation of domination. These glocal approaches then guided the development of global gymnastics styles, modes and norms, leading the FIG to take a reactionary approach to codification and equipment. First is the homology between the organisation of Soviet and Japanese societies and those of artistic gymnastics. Emphasising the work ethic, such cultural values resounded well with the requirements to achieve good gymnastics performances. ${ }^{56}$ Although there has been little research into Japan's gymnastic successes, we are able to explore the technical development of Soviet gymnastics in more detail, whose influence was felt worldwide. Indeed, since the late 1940s, a new trend was growing, under the impetus of the gymnasts of the Soviet Union, whose performances were based on more systematic research within new labs, using new discoveries from biomechanics of kinematics. This process originated in the Soviet Union, where experts across several sport-related disciplines contributed to creating a sports system geared towards international success. ${ }^{57}$ Since the end of the 1940s, training programmes were centralised, planned and very strictly organised; ${ }^{58}$ members of the Soviet teams were gradually selected according to their performances. Gymnasts benefits from constant medical control to prevent injuries. Coaches worked with biomechanics to design new skills. ${ }^{59}$ Moreover, they increased the frequency and duration of workouts for the best gymnasts.

As the Soviet Union was always at the top of international gymnastics, other countries followed its lead, basing their performances on Soviet ideals.

In this new context, the FIG tried to find a framework to control this technical and bodily revolution. The first official settlement was published in 1949 under the name of 'Code of Points', which provides for the assessment of exercises on the principle of the perfect 10 . This was also the first attempt at fulfilling the IOC's demand that its sports be quantifiable, which was important as certain sports' places in the Games were threatened as the IOC attempted to combat 'gigantism'. ${ }^{60}$ Although the Code of Points recorded and prescribed 'elements' gymnasts were performing, it remained a tool of reaction, rather than one that predicted future developments in the sport.

In addition to the marriage between science and sport influencing the sport from the Soviet Union outwards, equipment manufacturing technology would also contribute to a major qualitative leap in the development of 
gymnastics. Indeed, during the 1950s, the floor became more elastic, allowing more rebound force and therefore more flight time. Such developments continued every decade, with increasing mat thickness and apparatus padding designed to reduce risk of injury. However, such improvements actually encouraged gymnasts to perform riskier manoeuvres. ${ }^{61}$ Indeed, the increasing difficulty of skills was aided by the development of auxiliary equipment for training, such as the foam pit that enabled gymnasts to practise their acrobatic elements over a soft surface, according to a logic similar to that which enabled the 'Fosbury flop' in the High Jump. The introduction of softer equipment, particularly the foam pit, reduced the physiological stress from repetition, improved the quality of training, and especially encouraged greater risk taking. With apparatus developments officiated by the FIG, its frustration with increasing the difficulty levels is ironic.

During the 1960s, in parallel with these technological developments, gymnasts and coaches changed the sport from the bottom up. This decade saw the introduction of double somersaults, somersaults rebounding immediately into more somersaults, and somersaults with longitudinally rotating 'twists'. In the 1970s these developments were combined, with the introduction of somersaults with multiple rotations and twists around different axes, performed on a wider range of apparatus. ${ }^{62}$ Along with the creation of facilities to do so, such changes were a natural evolution of the sport. When performances were so closely matched in terms of execution, gymnasts sought to better their competition through exhibiting more difficult skills.

Herein the conquest of the performance is demonstrated, the pursuit of new gymnastics records beginning. ${ }^{63}$ Where other sports' records are remembered by times and distances, gymnastics' records became a dictionary of new elements and their inventors - all ranked on a scale of difficulty. The observed process is that of sportification of the different gymnastics disciplines, as they gradually distanced themselves from their physical education roots. In fact, in the Eastern countries, tradition in educational gymnastics was not as deeply rooted as in Western countries, where school physical education was based on the gymnastic exercises of the last third of the nineteenth century. This division in part explains the geographic development of success in sportive gymnastics. It not only removed preconceptions of 'gymnastics', which tied the Eastern bloc to the previous century, it also enabled gymnasts to draw on other disciplines, such as ballet and circus, to drive the sport. The evolution is most evident in women's artistic gymnastics in the 1970s, when

gymnasts appeared mechanical and robotic, and even somewhat strained. Their necks and legs were particularly tensed and the muscles of most parts of their bodies protruded, which, at least within a sporting context, suggested connotations of masculine gymnastics techniques $[\ldots] .{ }^{64}$ 
If the gymnastic movements were supposed to adhere to the ideals and representations of 'traditional' femininity and masculinity, differences still existed between the East and West. Thus, in a context where the rejuvenation of the best female gymnasts seemed to value the asexualisation of their bodies, as Natalie Barker-Ruchti suggested, or at least value a style of gymnastics that resulted in such bodies, some Western gymnasts relied on routines and behaviours of 'Lolita'. ${ }^{65}$ Such enactments may have been an effort to compensate for the decreasing age of Western competitors, and also a response to the WTC's continued emphasis on sexual maturity being necessary to femininity. ${ }^{66}$

If we recall that in Switzerland, like several other Western nations, female gymnasts were not allowed to compete until $1960^{67}$ - as evidence of the difference in ways of conceiving practice - we see there are two worlds and two ideologies of high performance sport that will clash in a singular way in gymnastics, leading to a sudden, sustainable and near total domination by Eastern countries. In this context, the FIG's leaders, especially those within the EC, tried to initiate steps to regulate the changes, particularly in women's artistic gymnastics. In 1971, Berthe Villancher made the following statement in her report for the General Assembly:

Medical reports have given a warning and pointed out the dangers of abusive training without the necessary control. They are right. The gymnasts, even those in the Olympic class, are not merely circus phenomena for whom the thrill of the performances accomplished masks the frequently disastrous physiological consequences. ${ }^{6}$

Such comments, however, were intended to encourage female gymnasts to revert back to a more 'feminine' version of the sport - attempting to embolden opposition to prepubescent gymnasts with the rhetoric of health, which would in turn see the sport return to its goals of exemplifying femininity. In the technical committees, other voices were influencing the sport, sometimes in opposite directions, especially as the committees were dominated by Eastern countries' officials. The quest for performance was streamlined, and the Soviet machine servicing high-level gymnastics with increasingly impressive technique forced others to follow in order to be in medal contention. In doing so, the Soviet machine was able to impose its view of the sport on others. After the mid-1970s, the committee set up to drive modern gymnastics - soon to be called 'rhythmic gymnastics' - would push the logic even further, both politically and as a new avenue to emphasise the 'femininity' that had been lost within WAG.

\section{Conclusion}

Our contribution shows in different ways that, like many other sports especially those presented in this special issue - international gymnastics is 
both a field of confrontation and a place of collaboration between the two blocs, as in several technical committees. Indeed, the organisational structure of the Federation showcases how Eastern and Western countries are deeply entangled whilst heading towards the same goal: promoting gymnastics. But, when one looks more closely at the various debates, we can see the lines drawn by the Cold War within the Federation. The famous South African case and the study of the EC could have led us towards a vision of a Federation dominated by white Western Men, still entangled within an 'apolitical' and 'educational' view of gymnastics. A closer look, however, shows a different perspective. The growing strength of the Soviet Union within the governmental structures becomes obvious when looking at the Technical Committees. The technical superiority of the Eastern countries in terms of results, thanks to a scientific quest for performance (allowed by both technological and bodily-improved technics) will allow these countries (and notably the Soviet Union) to draw a new idea of gymnastics. From the former pedagogical approach, gymnastics definitely gained its position as a sport. This is particularly spectacular when looking at Rhythmic Gymnastics, whose admission into the Olympic sphere sealed its entrance into the high performance sports club.

The evolution of the FIG during the Cold War allows us to call for a stronger analysis of what happened 'behind boycotts', and especially to have a closer look at less-known and less gender-oriented sporting institutions, beyond IOC and FIFA. In addition, to go further within this particular study of the FIG, it would be of interest to analyse the part played by Japan, as well as Middle-Eastern countries, within the institution. Similarly, expanding our documentary and archival material beyond the institution would also help us to deepen our understanding of the three dimensions analysed in this paper: institutional, geopolitical and technical influences on the governance of gymnastics.

\section{Notes}

1. Société Fédérale de Gymnastique, Société Fédérale de Gymnastique. 1832-1982 (Aarau: SFG, 1982).

2. As Central President of the Swiss Société Fédérale de Gymnastique in 1939, Charles Thoeni would play a key role in the governance of the Swiss gymnastics during the Second World War.

3. Stephen Wagg and David Andrews, eds., East plays West: Sport and the Cold War (London: Routledge, 2007); Christoph Berling and Evelyn Mertin, Freunde oder Feinde? Sportberichterstattung in Ost und West während des Kalten Kriege (Gütersloh: Medienfabrik Gütersloh, 2013); Heather Dichter and Andrew L. Johns, eds., Diplomatic Games: Sport, Statecraft, and International Relations since 1945 (Lexington: University Press of Kentucky, 2014).

4. Pierre Arnaud, 'Sport - a means of national representation', in Sport and International Politics. The Impact of Fascism and Communism on Sport, eds P. Arnaud and J. Riordan (London: Routledge, 1998), 5. 
5. Barbara Keys, Globalizing Sport. National Rivalry and International Community in the 1930s (Harvard: Harvard University Press, 2006).

6. Philippe Vonnard, Grégory Quin, and Nicolas Bancel, eds., Building Europe with the Ball. Turning Points in the Europeanisation of Football, 1905-1995 (Oxford: Peter Lang, 2016).

7. Peter Beck, 'Britain and the Cold War's 'Cultural Olympics': Responding to the Political Drive of Soviet Sport, 1945-58', Contemporary British History 19, no. 2 (2005): 169-85; Russ Crawford, The Use of Sports to Promote the American Way of Life During the Cold War: Cultural Propaganda, 1945-1963 (New York: Edwin Mellen Press, 2008); Allen Guttmann, 'The Cold War and the Olympics', International Journal 43, no. 4 (1988): 554-68; Wagg and Andrews, East Plays West.

8. FIG Official Bulletin, no. 1 (1953): 2, Swiss National Library.

9. FIG Official Bulletin, no. 4 (1971): 20, Archives of the Fédération Internationale de Gymnastique (presented as 'FIG Archives' in the next footnotes).

10. There are a few exceptions, published recently: Natalie Barker-Ruchti, 'Ballerinas and Pixies: A Genealogy of the Changing Female Gymnastics Body', The International Journal of the History of Sport 26, no. 1 (2009): 45-62; Roslyn Kerr and Camilla Obel, 'The Disappearance of the Perfect 10: Evaluation Rule Changes in Women's Artistic Gymnastics', The International Journal of the History of Sport 32, no. 2 (2015): 318-31; Georgia Cervin, 'Gymnasts Are Not Merely Circus Phenomena: Influences on the Development of Women's Artistic Gymnastics during the 1970s', The International Journal of the History of Sport 32, no. 16 (2015): 1929-46; Ann Kordas, 'Rebels, Robots, and All-American Girls: The Ideological Use of Images of Girl Gymnasts during the Cold War', in Girlhood: a Global History, eds H. Jennifer and A.V. Colleen (New Brunswick: Rutgers University Press, 2010), 195-214.

11. Jacques Ulmann, De la gymnastique aux sports modernes (Paris: Vrin, 1965); Peter C. McIntosh, Physical Education in England Since 1800 (London: Bell, 1968); Nicolas Bancel and Jean-Marc Gayman, Du guerrier à l'athlète (Paris: PUF, 2002); Gertrud Pfister, 'Cultural Confrontations: German Turnen, Swedish Gymnastics and English Sport - European Diversity in Physical Activities from a Historical Perspective', Culture, Sport, Society 6, no. 1 (2003): 61-91.

12. Until now, we haven't had the opportunity to visit FIG's archives, which moved to Lausanne during the first semester of 2017.

13. Keys, Globalizing Sport.

14. Grégory Quin, 'La reconstruction de la Fédération Internationale de Football Association (FIFA) après la Seconde Guerre mondiale (1944-1950). Jalons pour une histoire des relations sportives internationales', STAPS 106, no. 4 (2014): 21-35. Jenifer Parks, 'Red Sport, Red Tape: The Olympic Games, the Soviet Sports Bureaucracy, and the Cold War, 1952-1980' (PhD diss., UNC Chapel Hill, 2009). In the USSR, in 1946-1947, the VKP(b) Central Committee authorised Soviet federation to enter International federations in order to let Soviet sportsmen take part in international sports events. F. R7576, inv. 32, d. 99, 1. 97-98, State Archive of the Russian Federation (GARF), Moscow.

15. FIG Official Bulletin, no. 1 (1953): 14, Swiss National Library.

16. Report on the relation with Eastern countries, 27 January 1961, 1, Documents from the 'Politics and Sport' commission, Archives Société Fédérale de Gymnastique (Switzerland). 
17. Eric Monnin and Renaud David, 'The Melbourne Olympic Games in the Context of the International Tensions of 1956', Journal of Olympic History 17, no. 3 (2009): 34-40.

18. Letter from Otto Mayer to Président of the Federal Society of Gymnastique, 10 November 1956, Correspondence 1906-1959, Document from the Federation Internationale de Gymnastique, International Olympic Committee Archives (presented as 'IOC Archives' in the next footnotes).

19. FIG Official Bulletin, no. 4 (1956): 27, Swiss National Library.

20. FIG Official Bulletin, no. 4 (1956): 27-8, Swiss National Library.

21. Paul Dietschy, 'Making Football Global? FIFA, Europe, and the Non-European Football World, 1912-74', Journal of Global History 8 (2013): 279-98.

22. Evelyne Combeau-Mari, 'The introduction of Gymnastics and Sport by the Military Horseracing Society Life and Festivities - From Gallieni to Cayla (1896-1939)', The International Journal of the History of Sports 28, no. 12 (2011): 1586-604; Hamad S. Ndee, 'Germany and Eastern Africa: Gymnastics in Germany in the Nineteenth Century and the Diffusion of German Gymnastics into German East Africa', The International Journal of the History of Sport 27, no. 5 (2010): 820-44; James A. Mangan, The Games Ethic and Imperialism: Aspects of the Diffusion of an Ideal (London: Routledge, 1998).

23. Jennifer Hargreaves, Sporting Females, Critical Issues in the History and Sociology of Women's Sports (London: Routledge, 1994).

24. Grégory Quin, 'Le tournant 'sportif de la gymnastique féminine helvétique (1960-1985). L'Association Suisse de Gymnastique Féminine entre spécialisation et professionnalisation', Revue Suisse d'Histoire 65, no. 3, (2015): 429.

25. Sylvain Dufraisse, 'Les "Héros du sport" La fabrique de l'élite sportive soviétique (1934-1980)' (PhD diss., Université Paris 1 Panthéon-Sorbonne, 2016).

26. Ibid., 305.

27. Natalie Barker-Ruchti, 'Ballerinas and Pixies'; Anaïs Bohuon, 'On the Gender Tests: From an East/West Antagonism to a North/South Antagonism', International Journal of the History of Sport 32, no. 7 (2015): 965-79; Sandy Montanola and Aurélie Olivesi, eds., Gender Testing in Sport: Ethics, Cases and Controversies (London: Routledge, 2016).

28. Anke Hillbrenner, 'Soviet Women in Sports in the Brezhnev Years: The Female Body and Soviet Modernism', in Euphoria and Exhaustion. Modern Sport in Soviet Culture and Society, eds N. Katzer, S. Budy, A. Köhring, and M. Zeller (Frankfurt: Campus Verlag, 2011), 295-314.

29. Later on, in the 1980s and 1990s, those committees will be joined by others for General Gymnastics, Trampoline and Aerobic Gymnastics.

30. Letter from Charles Thoeni to Avery Brundage, 14 October 1960, General Correspondence 1960-1965, Document from the Federation Internationale de Gymnastique, Archives IOC.

31. Georgia Cervin, 'Gymnasts are Not Merely Circus Phenomena: Influences on the Development of Women's Artistic Gymnastics during the 1970s', The International Journal of the History of Sport 32, no. 16 (2015): 1929-46.

32. FIG Official Bulletin, no. 4 (1986): 60, FIG Archives.

33. Frank J. Cumiskey, 'A History of Gymnastics: The Olympiads and the Intervening Years, Chapter Viii', Personal Review in International Gymnast Magazine, 1983, 49, Document from the Federation Internationale de Gymnastique, General Information 1924-1986, SD4-Articles on Gymnastics 1980-1986, Archives IOC. 
34. Jim Barry, 'President's Report', Australian Gymnast Magazine 10, no. 19, October/November 1984, quoted in Georgia Cervin, 'A Balance of Power: Women's Artistic Gymnastics during the Cold War and its Aftermath' (PhD diss., University of Western Australia, 2016).

35. Barker-Ruchti, 'Ballerinas and Pixies'; Kordas, 'Rebels, Robots, and All-American Girls'; Cervin, 'Gymnasts are Not Merely Circus Phenomena'.

36. Marc Keech, 'The Ties that Bind: South Africa and Sports Diplomacy 19581963', The Sports Historian 21 (2001): 71-93.

37. Following Charles Thoeni's model, Arthur Gander will combine many positions within the institution: Vice-president until 1964 and then president from the Male Technical Committee from 1965 to 1972, he was also the acting president from FIG between 1966 and 1976.

38. Grégory Quin, 'Devenir un sport olympique. "Jalons pour une" Histoire comparée des développements de la gymnastique rythmique en France et en Suisse (1961-2011)' (Report for the French Olympic Academy Grant, 2014).

39. About football, we recommend the chapters from Kevin Marston and Philippe Vonnard in: Vonnard, Quin, Bancel, Building Europe with a Ball.

40. Although allegations of score fixing occurred before the Cold War, the impetus to pre-arrange scores significantly increased from 1952 onwards, with oral histories putting the Soviet Union at the centre of these claims. Cervin, 'Gymnasts are Not Merely Circus Phenomena'; Quin, 'Devenir un sport olympique’.

41. Quin, 'Le tournant 'sportif de la gymnastique féminine helvétique (19601985)'.

42. Scarlett Cornelissen, "Resolving 'the South Africa Problem": Transnational Activism, Ideology and Race in the Olympic Movement, 1960-91', The International Journal of the History of Sport 28, no. 1 (2011): 153-67.

43. Keech, 'The Ties That Bind'.

44. Maureen Margaret Smith, 'Revisiting South Africa and the Olympic Movement: The Correspondence of Reginald S. Alexander and the International Olympic Committee, 1961-86', The International Journal of the History of Sport 23, no. 7 (2006): 1193-216.

45. FIG Official Bulletin, no. 3 (1966): 2, FIG Archives.

46. FIG Official Bulletin, no. 4 (1966): 23, FIG Archives.

47. Keech, 'The Ties That Bind'

48. FIG Official Bulletin, no. 4 (1976): 74, FIG Archives.

49. FIG Official Bulletin, no. 4 (1977): 52, FIG Archives.

50. Cornelissen, “'Resolving 'the South Africa Problem' ”, 164.

51. Ibid.

52. Smith, 'Revisiting South Africa and the Olympic Movement'.

53. For instance, the Ghanaian representative at IOC, P.D. Quartey Junior, is expected to report on a regular basis on 'the question of racial discrimination in sports' at the Ghana Amateur Sport Council (Ghana National Archives, Minutes of the Meetings of the Standing Committee of the Ghana Amateur Sport Council, 1957-1959).

54. An all-around event combines the performance of a gymnast at every single apparatus.

55. Cervin, 'A Balance of Power', 2016.

56. About those processes, it is important to read: Catherine Mary O'Brien 'An investigation of the processes which produce elite women gymnasts in the USSR' (PhD diss., The Ohio State University, 1979). 
57. Dufraisse, 'Les “Héros du sport” La fabrique de l'élite sportive soviétique (19341980)'.

58. f. R7576, inv. 1, d. 576, 1. 177 State Archive of the Russian Federation (GARF), Moscow.

59. Vladimir Zaglada, One Coach's Journey from East to West: How the Fall of the Iron Curtain Changed the World of Gymnastics (Bloomington: Authorhouse, 2010), 12.

60. Cervin, 'A Balance of Power,' 2016.

61. Ibid.

62. Cervin, 'Gymnasts are Not Merely Circus Phenomena'.

63. Allen Guttmann, From Ritual to Record. The Nature of Modern Sports (New York: Columbia University Press, 1978).

64. Julia Weber and Natalie Barker-Ruchti, 'Bending, Flirting, Floating, Flying: A Critical Analysis of Female Figures in 1970s' Gymnastics Photographs', Sociology of Sport Journal 29 (2012): 37.

65. Barker-Ruchti, 'Ballerinas and Pixies'.

66. Cervin, 'Gymnasts are Not Merely Circus Phenomena'.

67. Eva Herzog, 'Frisch, Frank, Fröhlich, Frau'. Frauenturnen im Kanton BaselLandschaft (Basel: Verlag des Kantons Basel-Landschaft, 1995).

68. FIG Official Bulletin, no. 4 (1971): 50, FIG Archives.

\section{Disclosure statement}

No potential conflict of interest was reported by the authors.

\section{ORCID}

Georgia Cervin (D) http://orcid.org/0000-0002-3679-2500 